\title{
Utilizing Zakat for Attaining Sustainable Development Goals (SDGs) in Nigeria
}

\author{
Rafiu Ibrahim Adebayo \\ University of Ilorin
}

\begin{abstract}
Paper to be presented at the $4^{\text {th }}$ International Conference of Zakat (ICONZ)
7-8 October 2020, Surabaya, Indonesia
\end{abstract}

\begin{abstract}
At the United Nation Conference in Stockholm in the early 1970s, the idea of sustainable development was mooted. It became a global phenomenon in the year 2000 when the United Nations (UN) declared the Millennium Development Goals (MDGs) with over one hundred and eighty-nine member states and about twenty-three international organizations. With the expiry date of the Millennium Development Goals (MDGs) in 2015, the Sustainable Development Goals (SDGs) came in vogue. The SDGs as a global project could only be attained through joint efforts of all sectors of human life, religion being one. In human history, religion plays significant developmental roles, hence a strong factor in attaining developmental goals. Islam in particular could not be left out in any developmental project, as it is not only a religion and but also a way of life. Indeed, the maqasid ash-shari'ah are meant for all-round development and protection of human life - religion (Din), life (Hayat), procreation (Nasl), Property (Māl) and Intellect $\left({ }^{c} A q l\right)$. This study is designed to specifically relate the institution of zakat in Islam to attainment of the Sustainable Development Goals (SDGs) with particular reference to Nigeria as a country. Historical, descriptive and exegetical methods are adopted for this purpose. The paper therefore concludes that zakat can be a veritable tool for achieving the SDGs if properly harnessed, monitored and utilized for the purpose it is meant.
\end{abstract}

Keywords: zakat, sustainable development, goals, Nigeria

\section{INTRODUCTION}

The concept of sustainable development is defined as "the efforts at improving the socio-economic and ecological status and at exploiting and processing the environment or natural resources for the purpose of improving the quality of life in such a way that the needs of the future generations are not jeopardized" (Adebayo, 2010: 219). The Millennium Development Goals (MDGs) set by the United Nations came to an end in 2015 with relative success recorded. This paved way for the Sustainable Development Goals (SDGs) with a target date of 2030 for the overall attainment of the goals though with specific earlier dates set for the attainment of some of the specific goals (Akanni, 2018). Some of the reasons why the MDGs recorded little success were corruption, bad leadership and lack of accountability on the part of the handlers of each of the MDGs projects. Religion was not also allowed to feature in the attainment of the goals. This lacuna if not filled may equally be a stumbling stone to attaining the SDGs.

There is no doubt that religion has played and is still playing a crucial role in the attainment of any developmental project. According to Owoyemi (2018), spirituality is not antagonistic to physical development, as both aid each other in achieving a better society for humankind. However, most adherents of religion only exhibit extrinsic religiosity instead of intrinsic religiosity to achieve their selfish ends. 
Many scholars had written on religion in relation to development, MDGs and SDGs. Such include Chapra (2008), Barau (2004), Karwai (2012), MuhammadThani (2019) and Akanni (2018). While some looked at development from pure economic perspective, some studied it from environmental perspective. MuhammadThani (2019) studied the implementation of the MDGs in Kwara State Nigeria, while Akanni (2018) looked at the SDGs from Islamic Perspective. As relevant as Akanni's work to this present study, this work has an in-depth study of the SDGs from pure zakat perspective, a major pillar of Islam with a view to anaylsing how this pillar can be utilized and has been utilized to attain the SDGs in Nigeria.

\section{SUSTAINABLE DEVELOPMENT GOALS (SDGS)}

In the early 1970 s at the United Nation Conference in Stockholm, the idea of sustainability was first presented. Worried by the high rate of depletion of nature, the International Union for Conservation of Nature published the World Conservation Strategy sometimes in 1980s. There was another report in 1987 by the World Commission on Environment and Development (WCED), all which gave credence to the fact that though the world was developing, but at the same time, the development had to be sustained but without jeopardizing the future generations. The worry of world leaders culminated in the declaration of the Millennium Development Goals (MDGs) which was signed in the year 2000 by more than one hundred and eighty-nine member states of the United Nations (UN) as well as other twenty-three other international organizations.

Millennium Development Goals (MDGs) are commitments made by world governments to address poverty and promote sustainable development in developing countries of the world. The
MDGs provide the frameworks committing countries both developed and developing, to a set of eight mutually re-enforcing, ambitious and targets-oriented goals. The goals are:

1) eradication of extreme poverty and hunger;

2) Achieving universal primary education;

3) promoting gender equality and empowering women

4) reducing child mortality

5) improving maternal health

6) Combating HIV/AIDS, Malaria and other diseases

7) ensuring environmental sustainability; and

8) develop a global partnership for development

By the year 2015 which was the targeted year for the achievement of the above goals, member countries could assess themselves to determine the success or otherwise of the programme. A doctoral thesis which had a post-evaluation of the Implementation of the Millennium Development Goals (MDGs) in Kwara State, Nigeria, for example did not give the implementation a pass mark, as the researcher mentioned corruption as a major factor that hampered its success (Muhammad-Thani, 2019). He observed mere political propaganda as constituents of the acclaimed achievements of the programme in the State.

The relative success of the Millennium Development Goals however culminated in the formulation of the Sustainable Development Goals which were ratified on 25 September 2015 by the 193-Member United Nations General Assembly (UNGA). The goals are seventeen in number, with 169 targets. The goals are:

1) End poverty in all its forms everywhere.

2) End hunger, achieve food security and improve nutrition and promote sustainable agriculture. 
3) Ensure healthy lives and promote well-being for all at all ages.

4) Ensure inclusive and equitable quality education and promote lifelong learning opportunities for all.

5) Achieve gender equality and empower all women and girls.

6) Ensure availability and sustainable management of water and sanitation for all.

7) Ensure access to affordable, reliable, sustainable and modern energy for all.

8) Promote sustained, inclusive and sustainable economic growth, full of productive employment and decent work for all.

9) Build resilient infrastructure, promote inclusive and foster innovation.

10) Reduce inequality within and among countries.

11) Make cities and human settlements inclusive, safe, resilient and sustainable.

12) Ensure sustainable consumption and production pattern.

13) Take urgent action to combat climate change and its impacts.

14) Conserve and sustainably use the oceans, seas and marine resources for sustainable development.

15) Protect, restore and promote sustainable use of terrestrial ecosystems, sustainably manage forests, combat desertification.

16) Promote peaceful and inclusive societies for sustainable development, provide access to justice for all and build effective, accountable and inclusive institutions at all levels.

17) Strengthen the means of implementation and revitalize the global partnership for sustainable development.

A critical analysis of the above goals reveals that some of them are overlapping. Take for instance, the first goal is all-embracing. The World Bank
(2004) sees poverty as a condition of nonavailability of basic human needs such as healthcare, education, food, water, and shelter. Going by this definition, one sees that the first goal addresses some other goals in the list. For instance, goals 4 and 6 - 11 overlap one another, as they are all working towards provision of basic human needs.

\section{ZAKAT AS AN INSTITUTION}

The institution of zakat displays that Islam is not restricted to the four walls of the mosque, rituals and 'aqidah alone. It does not limit itself to relationship between man and his Creator, but as well takes care of human relationship. Given that man is not equally financially blessed, Islam prepares a means through which wealth can be circulated so that the less privileged will enjoy some levels of economic security. Zakat as an institution is an obligatory charity where a certain fixed proportion of the wealth of the rich as well as every kind of the property liable to zakat of a Muslim is paid annually for the benefit of the poor in the Muslim community. Through this, social justice, which is a major factor for a peaceful society is ensured. This fundamental pillar of Islam is compulsory upon all Muslims who have wealth that reaches the minimum payable level (nisab) and which is in the custody of its owner up to a year (hawl).

The Qur'an mentions the essence of giving zakat as a means of purifying the property of the payer (Q9:103). It is therefore likened to the bile, which should not be consumed with the flesh if the owner wants to enjoy the consumption of the flesh. In the same vein, it purifies the heart of the recipient from hatred, envy and uneasiness and as well fosters goodwill and warm wishes for the payer. Other functions of zakat as highlighted by Chapra (1980) include eradication of poverty; creation of full employment; promotion of stability in the real value of money; maintaining law 
and order; ensuring social and economic justice; arranging social security; fostering equitable distribution of income and wealth; and harmonizing international relations, among others.

Qur'an 9: 60 gives the list of those eligible to collect zakat thus:

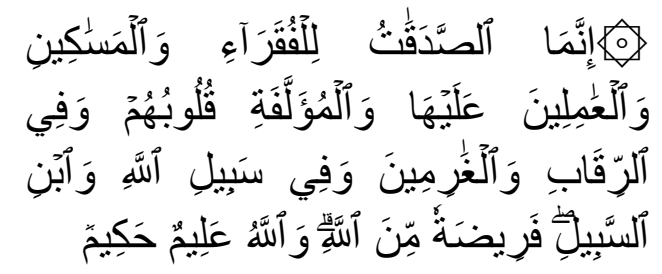

Zakah expenditures are only for the poor and for the needy and for those employed to collect [zakah] and for bringing hearts together [for Islam] and for freeing captives [or slaves] and for those in debt and for the cause of Allah and for the [stranded] traveler - an obligation [imposed] by Allah. And Allah is Knowing and Wise.

According to al-Ghazali (1980), a poor is a pauper who does not have what is enough for him to attend to his basic needs thereby begging. The needy on the other hand does not have much and does not ask others to give him charity. In other words, a needy is temporarily incapacitated. He needs to be assisted a bit to overcome his challenges. A good example is a graduate who has the ability to work but has not been able to get job to feed himself. The poor however is handicapped physically and needs to be assisted constantly to meet his basic needs. According to Shah (2010), fuqara' and masakin include orphans, divorced, old people, handicapped, patients, permanent low income, families of the prisoners and missing people and students.

Zakat is not restricted to cash only; it is also payable on gold, silver. $2.5 \%$ or $1 / 40$ of the nisab is deductible from each of these. 85 grams of goal, which equals 20 dinar and 595 grams of silver, which equals 200 dirhams are the nisab for gold, silver and currency respectively. In addition, the
Qur'an confirms giving zakat from agricultural products when it reads:

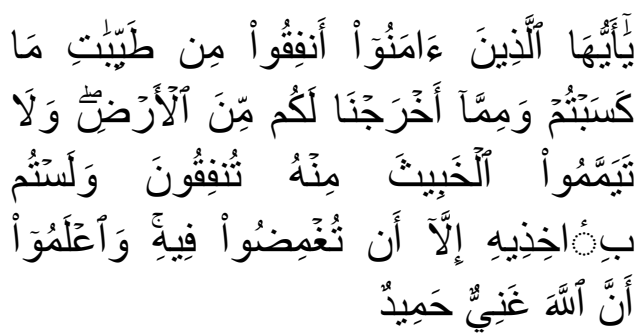

O you who have believed, spend from the good things which you have earned and from that which We have produced for you from the earth. And do not aim toward the defective therefrom, spending [from that] while you would not take it [yourself] except with closed eyes. And know that Allah is Free of need and Praiseworthy (Q2: 267)..

Apart from agricultural products, livestock are also zakatable. The table below gives the summary of zakat due on livestock.

Table 1. Zakat on livestock

\begin{tabular}{|c|c|c|}
\hline $\begin{array}{l}\text { Nature of } \\
\text { livestock }\end{array}$ & $\begin{array}{l}\text { Nisab and } \\
\text { range of } \\
\text { livestock }\end{array}$ & $\begin{array}{l}\text { Zakat } \\
\text { deductible }\end{array}$ \\
\hline \multirow[t]{10}{*}{ Camels } & $5-9$ & $\begin{array}{l}1 \text { one year old } \\
\text { goat or } 6 \text { month } \\
\text { old sheep }\end{array}$ \\
\hline & $10-14$ & $\begin{array}{l}2 \text { one year old } \\
\text { goat or } 6 \text { months } \\
\text { old sheep }\end{array}$ \\
\hline & $15-19$ & $\begin{array}{l}3 \text { one year old } \\
\text { goats or sheep }\end{array}$ \\
\hline & $20-24$ & $\begin{array}{l}4 \text { one year old } \\
\text { goats or sheep }\end{array}$ \\
\hline & $25-35$ & $\begin{array}{l}1 \text { One year old } \\
\text { she-camel }\end{array}$ \\
\hline & $36-45$ & $\begin{array}{l}\text { One two year old } \\
\text { she-camel }\end{array}$ \\
\hline & $46-60$ & $\begin{array}{l}\text { One three year } \\
\text { old she-camel }\end{array}$ \\
\hline & $61-75$ & $\begin{array}{l}\text { One four year old } \\
\text { she-camel }\end{array}$ \\
\hline & $76-90$ & $\begin{array}{l}\text { Two } 2 \text { year old } \\
\text { she-camels }\end{array}$ \\
\hline & $91-120$ & $\begin{array}{l}\text { Two } 3 \text { year old } \\
\text { she-camels }\end{array}$ \\
\hline
\end{tabular}




\begin{tabular}{llll}
\hline $\begin{array}{l}\text { Nature of } \\
\text { livestock }\end{array}$ & $\begin{array}{l}\text { Nisab and } \\
\text { range of } \\
\text { livestock }\end{array}$ & $\begin{array}{l}\text { Zakat } \\
\text { deductible }\end{array}$ \\
\hline & $\begin{array}{l}121 \\
\text { more }\end{array}$ & or & $\begin{array}{l}\text { One bint labun } \\
\text { for every 40 } \\
\text { camels and one } \\
\text { hiqqah for every } \\
50 \text { camels. }\end{array}$ \\
\hline Cows & $30-39$ & $\begin{array}{l}\text { 1 two year old } \\
\text { male calf }\end{array}$ \\
\cline { 2 - 3 } & $40-59$ & $\begin{array}{l}\text { 1 three year old } \\
\text { cow }\end{array}$ \\
\cline { 2 - 3 } & $60-69$ & $\begin{array}{l}\text { 2 two year old } \\
\text { female calf }\end{array}$ \\
\hline Sheep & $40-120$ & 1 sheep \\
\hline
\end{tabular}

\begin{tabular}{lll}
\hline $\begin{array}{l}\text { Nature of } \\
\text { livestock }\end{array}$ & $\begin{array}{l}\text { Nisab and } \\
\text { range of } \\
\text { livestock }\end{array}$ & $\begin{array}{l}\text { Zakat } \\
\text { deductible }\end{array}$ \\
\hline & $121-200$ & 2 sheep \\
\cline { 2 - 3 } $201-300$ & 3 sheep \\
\cline { 2 - 3 } $310 \quad$ or & $\begin{array}{l}\text { Extra one sheep } \\
\text { for every 100 } \\
\text { more }\end{array}$ \\
\hline
\end{tabular}

Source: Al-Qaradawi, Fiqh az-zakat, vol. 1, 1994.

Figure 1 indicates the zakat mobilization region as well as zakat distribution region.

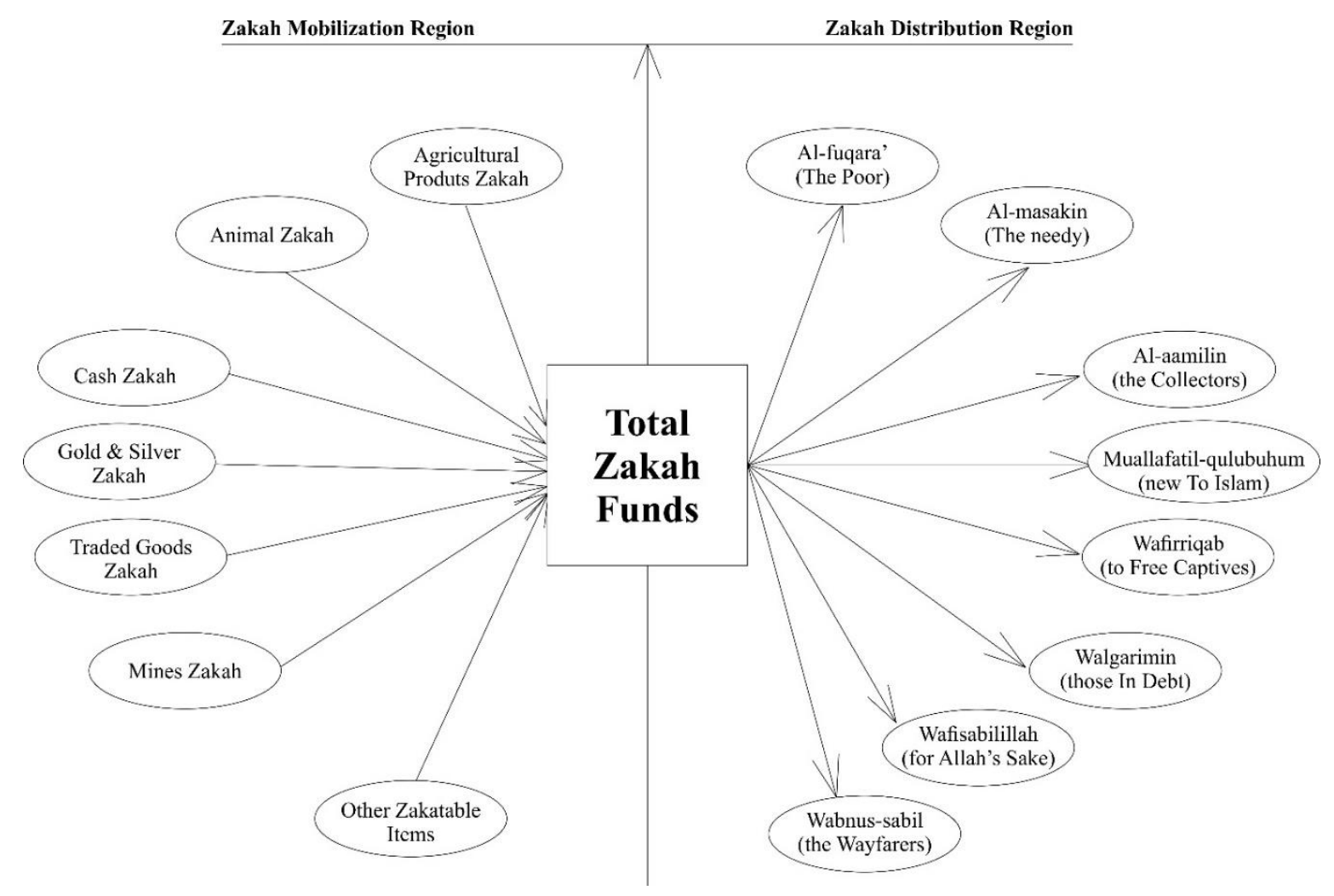

Figure 1. Zakat mobilization region as well as zakat distribution region

Source: Adapted from Mustafa et.al 2018

\section{THE RELEVANCE OF ZAKAT FOR ATTAINING SUSTAINABLE DEVELOPMENT GOALS (SDGS)}

Zakat is relevant to virtually all the SDGs goals. The first goal, which is poverty eradication, may be achieved from the recipients of zakat. Poverty is considered a bane to any development. Zakat is designed and programmed to address the causes of poverty and make provision for its alleviation. As such, the Prophet prayed vehemently against faqr (poverty). The institution of zakat aims at alleviating poverty, hence enjoins the rich to give a portion of their wealth to the poor in the 
society. Giving out to the poor in order to alleviate their poverty is closely attached to observance of salat in many verses of the Qur'an. This underscores the unique position of assisting the less privileged in the society in Islam. In addition, the recipients of zakat are mainly the poor (alfuqarau) and the needy (al-Masakin).

Another aspect of zakat relevant to the first goal is the 'amilina alayha (the workers of zakat). In other words, zakat provides job opportunity, hence reduces the percentage of job seekers who could have constituted additional burden to the society. Zakat is therefore capable of creating job opportunity in aspects of searching for those eligible to pay, those eligible to receive zakat, keeping records, assessing and collecting dues and distribution of the proceeds (Qaradawi, 1999).

Another unique characteristic of zakat is that it is levied not on the income of its payers, but on accumulated net worth which is in one possession for up to a year (Adebayo, 2011). This implies that the giver is not unnecessarily burdened to affect his wealth. It also encourages investment so that wealth is not left idle. As such, this implies shifting of taxes from the income of the payers to the accumulated wealth from such income.

The second goal, which is ending hunger, achieving food security, improving nutrition, and promoting sustainable agriculture is equally within the scope of zakat. As mentioned earlier, zakatable items are not limited to cash; agricultural products as well as livestock such as sheep, goats, cows and camels are included. The Qur'an 6: 141 informs that zakat is deductible from agricultural products when it reads:

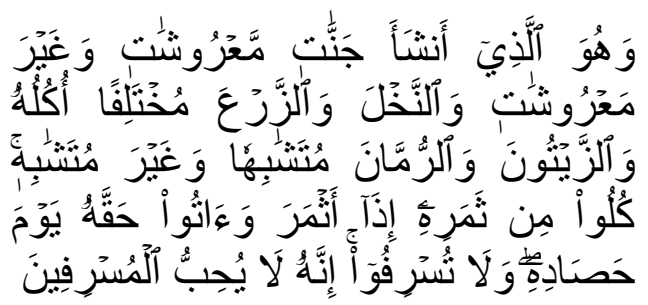

And $\mathrm{He}$ it is who causes gardens to grow, [both] trellised and untrellised, and palm trees and crops of different [kinds of] food and olives and pomegranates, similar and dissimilar. Eat of [each of] its fruit when it yields and give its due [zakah] on the day of its harvest. And be not excessive. Indeed, He does not like those who commit excess.

That zakat is deductible on fruits, animals and agricultural produce indicated that it affords the poor access to good nutritious and balanced diet. Apart from zakat, there is also the zakat al-fitr, which is paid mostly in form of food items for the poor, at the expiration of Ramadan fast. This is to take care of the poor during the festive period at least to have something to eat.

The third goal, which is ensuring healthy lives and promoting well-being for all at all ages, is accommodated in the institution of zakat. This is because zakat ensures healthy living between the rich and the poor. This is because it aids redistribution of wealth in the society so that wealth is not concentrated in the hands of the rich alone. It therefore facilitate sense of goodwill, which is an ingredient of healthy living in the society. It also encourages healthy living between the Muslims and non-Muslims as it is argued that nonMuslims could also be accommodated in the list of those eligible to receive zakat. It was reported that 'Umar, the second caliph passed by an old and blind Jew who was begging. 'Umar was said to have held the hand of the man and took him to his house, gave him something and sent him to the public treasurer and said: "Take care of this man, for by Allah, we have used his childhood and then neglected him at his old age" (Aqlah, 1983).

It has to be noted that one of the categories of recipients of zakat is for Allah's cause ( $F i$ sabilillah). This is being debated among jurists to have included among others using zakat for all types of 
struggles in the righteous cause and on provision of social welfare programmes and projects as well as manpower training or education in scientific and technical fields that are of direct benefits to the poor. It is therefore argued that zakat can be used to provide social services like hospitals and schools and even for factories which create employment opportunities for the people (Shah, 2010). This implies that goals 4, 6, $7,8,9,11$ and 12 goals of the SDGs are captured in zakat.

Goal 5, which is achieving equality and empower all women and girls is equally relevant in the realm of zakat. This is because zakat is not gender discriminatory. A woman can fall into any of the categories of those who could receive zakat. Indeed, widows are major recipients of zakat. In the same vein, experience has showed that zakat has no geographical boundaries, as philanthropic zakat hands had been extended by some well-to-do Muslim dominated countries to other developing countries of the world. Ever before the promulgation of anti-money laundering policies which halted this gesture, international orgaizations like the International Islamic Relief Organisation (IIRO), which is an affiliate of the Muslim World League (MWL), had carried out some projects in different parts of the world. For instance, the organization established a clinic in Jalingo, Taraba State in Nigeria; mosques in Ifon and Ibadan; and Arabic schools in Ibadan, Ilorin and Kaduna. It is also on record that in 1992, the IIRO sent relief to drought victims and refugees fleeing war in Somalia. The Saudi NGO also distributed food and managed six clinics attached to three camps of Azeri displaced persons. It also took care of orphans and supplied hospitals with drugs in Agdash and Baku. Also, Al-Haramain Islamic Foundation (HIF), a charitable body with its headquarters in Riyadh, Saudi Arabia with Nigeria office in Ibadan, made donations to orphanage and rehabilitation centres; paid hospital bills for patients who could not afford payment; and established a vocational centre in Ibadan where women particularly orphans and widows learnt tailoring, weaving, soap-making and other vocations (Adebayo, 2016). This suggests that zakat, in line with goal 10 of the SDGs, assists in reducing inequality within and among countries. This is possible in view of the fact that it is not out of place to take zakat out of one geographical location to another.

Goals 13, 14 and 15 have to do with taking urgent action to combat climate change and its impacts; conserve and sustainably use the oceans, seas and marine resources for sustainable development; and protect, restore and promote sustainable use of terrestrial ecosystems, sustainably manage forests, combat desertification. These goals could be derived from the lessons derivable from the institution of zakat. It has to be noted that Islam demonstrates modesty in the institution of zakat, which prescribes moderate charges in the amount to be paid as zakat. Zakat also minimizes the high rate at which people become materialistic for economic purposes. The materialistic tendencies in him make him to exploit natural resources without conservation and so it metamorphosed to greediness and excessiveness whereby he obtains more than what he needs. According to Akhtaruddin, et.al, (1997: 93), as at 1990, coal reserves were estimated at 534 billion tonnes and those of natural gas at 104 billion tonnes. Also, oil reserves were estimated at 140 billion tonnes and this would last for less than 100 years, while at the 1990 rate of consumption, coal would last for 200 years and gas for less than 150 years. With this, it is glaringly clear that climate change becomes inevitable in the face of non-conservation of natural resources.

Closely related to the above are goals 16 and 17, which are out to promote peaceful and inclusive societies for sustainable development, provide access to justice for all and build effective, 
accountable and inclusive institutions at all levels; and as well strengthen the means of implementation and revitalize the global partnership for sustainable development. Zakat is out to promote peaceful and inclusive societies. Both the poor and the rich are satisfied and are working together harmoniously as the sympathy for the poor are awakened in the hearts of the rich, while the poor also suppresses his ill feeling and bad wishes for the rich through unnecessary and unhealthy envy, since he has his own share from the wealth of the rich.

\section{ZAKAT ADMINISTRATION IN NIGERIA FOR SUSTAINABLE DEVELOPMENT IN NIGERIA}

The history of zakat administration in Nigeria varies from one geographical area to another. What is known about zakat at initial stage in every zone is that its collection and distribution were not properly coordinated, as wealthy individuals used their discretion to distribute it without much knowledge of the rules guiding it. After deducting whatever pleased them from their wealth, it was taken to a Muslim cleric around. The cleric himself saw the zakat paid to him, his right, and so there was no need to redistribute it to the less privileged around. The history however changed in the southwestern part of the country when some wealthy individuals set up a committee to disburse their zakat. Worried by the increasing number of indigent Muslims, late Alhaji Moshood Kashimawo Abiola came up with Abiola Zakat Welfare Fund, earmarking certain amount to it on annual basis. Also, late Chief AbdulWahab Folawiyo, a renowned philanthropist used to give out zakat to some Islamic organizations and certain individuals during the month of Ramadan. In the same vein, another philanthropist, late Alhaji Mufutau Lanihun, a business mogul in Ibadan, Oyo State used to give out zakat to groups and individuals during the month of Ramadan.
According to Ashafa (2016), some Muslim organizations like the National Council of Muslim Youth Organizations (NACOMYO), Muslim Students' Society of Nigeria (MSSN), Nasrullahi Fathi Society (NASFAT), among others benefitted from the zakat distribution of Mufutau Lanihun.

The administration of zakat in the northern part of Nigeria is a bit organized, as it attracts government intervention. The introduction of Shari'ah penal code in some of the states in the North greatly assisted the institution. Some state governments have special commission to take care of the collection and disbursement of zakat funds. There is for instance, the Kano State Zakah and Hubusi Commission (KSZHC) in Kano State, as well as the Zamfara State Zakat and Endowment Board in Zamfara State, among others. Meanwhile, in the southwestern part of Nigeria, zakat is handled by some non-governmental agents, which collect and disburse it to recipients using different measures. Ashafa (2016) identified and assessed the modus operandi of thirteen of such organizations in southwestern Nigeria.

Successes recorded in the performance of various governmental zakat bodies in the northern part of the country as well as the non-governmental organizations in the southwestern Nigeria indicates that zakat is a viable tool for poverty alleviation in Nigeria and it is a useful weapon to achieve the Sustainable Development Goals. The Zakat and Sadaqah Foundation has demonstrated this in numerous ways it uses to attend to the immediate needs of the people. It embarks on different support programmes like educational support, emergency relief, widows/orphans support, medical supports and entrepreneurial supports. In 2018 to be specific, the Foundation distributed zakat worth two hundred and four million, seven hundred and seventy thousand and eighty-five naira $(\mathrm{N} 204,770,085)$ to 2,208 recipients of various categories of people across 
seventeen states of the federation. The Foundation also embarked on Entrepreneurial Development Project (EDP), which was designed to bring Nigerian youth with entrepreneurial skills to compete and display their creative ideas and business plans (www.zakatandsadaqa.org.ng accessed on 21 March 2020). In addition, numerous applicants had received material assistance from the Foundation in form of empowerment. Such working materials as computer set, laptop, deep freezers, generator, tricycles, printers, shoe making machines, embroidering machines, sewing machines, stabilizers, photo-printers, photocopy machines and wheel chairs for physically disabled among others had been distributed to people (Adebayo \& Ashafa, 2019).

Apart from the Zakat and Sadaqah Foundation, there is also the Islamic Forum in Lagos State, which spends about $95 \%$ of the zakat collected on education grants, orphanages and charity homes. In addition, donation of learning materials are also made to educational institutions, as well as relief materials to people as occasions demand. Summarily, education of the less privileged, health concern and debtors are also captured regularly in the priority list of zakat administration in southwestern Nigeria. The story of zakat disbursement is almost the same in the northern part of the country. In a study carried out by Mustafa et.al (2017), it was noted that in Kano State alone, there was potentials to generate as much as $\mathrm{N} 25$ billion (equivalent US $\$ 80.6 \mathrm{~m}$ at N310 per US\$) from zakat payers if qualified and conscious Zakat payers of one million people would pay $\mathrm{N} 25,000$ each from their zakatable cash of N1,000,000 only.

A crucial aspect, which receives utmost attention in the northern part of the country, is zakat on agricultural products and livestock. This gives the zakat collection in the northern part an upper hand over those from the southwestern part of the country where these have been grossly neglected as if they are not parts of the zakatable items. The table below illustrates zakat on farm produce collected in Niger State by the Zakat and Endowment Board of the State.

Table 2. 2004-2017 Zakat on grains collected by the Niger State Zakat and Endowment

Board

\begin{tabular}{cc}
\hline Years & $\begin{array}{c}\text { Bags of grains } \\
\text { collected }\end{array}$ \\
\hline $\begin{array}{c}\text { September 2004 - } \\
\text { June 2005 }\end{array}$ & 524.5 \\
\hline 2006 & 470 \\
\hline 2007 & $1,083.5$ \\
\hline 2008 & 774.4 \\
\hline 2009 & 1,384 \\
\hline 2010 & 1,335 \\
\hline 2011 & 3,065 \\
\hline 2012 & 1,975 \\
\hline 2013 & 1,967 \\
\hline 2014 & 1,838 \\
\hline 2015 & 1,517 \\
\hline 2016 & $1,339.5$ \\
\hline 2017 (January-May) & 864.5 \\
\hline
\end{tabular}

Source: Adapted from Shittu \& Ndaman (2019)

\section{CONCLUSION}

Zakat indicates that Islam is not restricted to mere observance of the daily prayers and other rituals. It has social and economic significance which if properly harnessed can better the lots of many people in the society. It should be mentioned that religion should be put into consideration whenever any policy is being made both at national as well as international levels. The Millennium Development Goals could not achieve much in Nigeria because religion was downplayed and was not allowed to feature in the project. To achieve sustainable development goals therefore, religion should be given the desired attention needed in order to provide spirituality that would give soul to each of the goals. 
Zakat collection and distribution should be given serious attention in Muslim communities. The poor should be attended to through it and other means. Where this is not given the desired attention, there is every probability that calamity of all nature would continue to ravage such community. Different organizations championing zakat administration in the southwestern Nigeria are commendable, and it gives a signal that where governments are not forthcoming, the Muslim community can take the bull by the horn to chart an Islamic course to assist the downtrodden in the society. That notwithstanding, all aspects of zakat should be explored to attain maximum benefits for the poor.

\section{REFERENCES}

Adebayo, R.I. (2011). Zakat and Poverty Alleviation: A Lesson for the fiscal policy makers in Nigeria. Journal of Islamic Economics, Banking and Finance. 7(3). 25-42.

Adebayo, R.I. (2011). A Study of some factors contending with sustainable development in Nigeria: A Muslim Perspective; in Opoku, SA.K (ed), Culture, Science and Sustainable Development in Africa; (A Refereed paper from the first University of Cape Coast and University of Ilorin Joint International Conference); Cape Coast, The University Press.

Adebayo, R.I. (2016). Dividends of International Islamic Organisations in Nigeria, in Religion in Contemporary Nigeria; Quadri, Y.A., Omotoye, R.W \& Adebayo, R.I. (eds) London: Adonis \& Abbey Publishers Ltd.

Adebayo, R.I. and Ashafa, S.A. (2020), Zakat Distribution in the Context of Shari'ah corporate governance: Evidence from South-Western Nigeria" in Handbook of Research on Theory and Practice of Global
Islamic Finance; Abdul Rafay (ed), 161-178: Hershey, USA, published by IGI Global.

Akanni, A.A. (2018), "Islam and the Attainment of the Sustainable Development Goals (SDGs) in Nigeria", in Quadri, Y.A.; Omotoye, R.W. and Adebayo, R.I. (eds), Religion and Development in Nigeria. London: Adonis and Abbey Publishers Ltd.

Akhtaruddin, Ahmad, Majid, H.A. Hashim \& Ghazi al-Hachim, (1997), Islam and the Environmental Crisis; London, Ta Ha Publishers Limited.

Al-Ghazali, A.A. (1980), Ihya' 'ulum adDin, Cairo: Dar Ash-Sha'b.

Al-Qaradawi, Y. (1999), Figh az-Zakat: A Comparative study of the rules, regulations and philosophy of Zakah in the light of the Qur'an and Sunnah. London: Dar al-Taqwah Ltd.

Al-Qaradawi, Y. (1994) Fiqh az-zakat, vol. 1, Cairo: Maktaba Wahbat.

Aqlah, M (1983), Historical Application of zakat. Proceedings of $1^{\text {st }}$ International Conference on Zakat; Kuwait.

Ashafa, S.A. (2016). Practice of Zakat and Poverty Alleviation in SouthWestern Nigeria. Unpublished PhD Thesis, Department of Religions, University of Ilorin, Ilorin.

Barau, A.S. (2004). Environment and Sustainable Development in the Qur'an. Kano: IIIT Nigeria.

Chapra, M.U. (2008). The Islamic Vision of Development in the Light of the Maqasid al-Shari'ah. Jeddah: Islamic Development Bank.

Chapra, M.U. (1980). The Islamic Welfare State and its Role in the Economy; in Khurshid Ahmad (Ed), Islamic Economics. Jeddah: International Centre for Research in Islamic Economics, King Abdul Aziz 
University \& the Islamic Foundation, U.K.

Karwai, S.A. (2012). "Islamic Economic Development." In Karwai, S.A, Habib, A.G and Jibril, B.T (eds). Islamic Economics: A Book of Readings. Kano: IIITN

Muhammad Thani, M. (2019), A PostEvaluation of the implementation of the Millennium Development Goals (MDGs) in Kwara State, Nigeria, from Islamic Perspectives" Unpublished $\mathrm{Ph}, \mathrm{D}$ thesis, Department of Religions, University of Ilorin.

Mustafa, D.; Baita, A.J; Adhama, H.D \& Sabo M. (2018). Potential Revenue of Zakah Institution for Poverty Alleviation in Kano State, Nigeria. Final Report on Zakah Institution for Poverty Alleviation in Kano State, Nigeria submitted to Islamic Research and Training Institute (IRTI), Jeddah- Saudi Arabia. Jumada al-Awwal, 1439H.

Mustafa, D. Sabiu, T.T. \& Bello, A.I. (2017). Re-engineering the institutions of Zakah and waqf for economic empowerment in Kano State, Nigeria. Northwest Journal of Social and Management Sciences 1(1), 34-53.

Owoyemi, M.Y. (2018) "Religion and Development: Religiosity and its Effects on Development in Nigeria" in Quadri, Y.A.; Omotoye, R.W. and Adebayo, R.I. (eds), Religion and Development in Nigeria. London: Adonis and Abbey Publishers Ltd.

Shah, S.S (2010) “ Investment of Zakat Fund: Modern Juristic Debate and Modes of Financing". Journal of Islamic Banking and Finance. 27(3), 25-38.

Shittu, A.D and Ndama, M.N. (2019), Shari'ah and Economic Justice in Nigeria: The Experience of the Niger
State Zakāt and Endowment Board (2001-2017). An unpublished Research report.

Rafiu Ibrahim Adebayo

Professor at Department of Religions, University of Ilorin, Ilorin, Nigeria adrafhope@yahoo.com, rafiu@unilorin.edu.ng 
